\title{
Определение параметров локальных событий по данным Карельской сейсмической сети
}

\section{Зуева И.А.}

Институт Геологии КарНЦ РАН, ФИЦ «Карельский научный центр РАН», Петрозаводск , ek92wa@mail.ru

Аннотация. Республика Карелия характеризуется слабой сейсмичностью. По результатам обработки последних 20 лет магнитуды сейсмических событий, зарегистрированных в данном регионе не превосходили значение 3,2. Землетрясения могут происходить 1-2 раза в год. Самыми частыми сейсмическими событиями на записях Карельской сейсмической сети являются промышленные взрывы. Для определения параметров локальных событий используются различные методы и программы локации, чтобы получить наиболее точные результаты. Ежегодно регистрируются более 200 сейсмических событий в разных районах Карелии.

Ключевые слова: сейсмичность, очаг, сейсмическая станция, эпицентр, магнитуда, карта сейсмичности.

\section{Determination of parameters of local events according to the Karelian seismic network}

\section{Zueva I.A.}

Institute of Geology, Karelian Research Centre, Russian Academy of Sciences, Petrozavodsk, ek92wa@mail.ru

Abstract. The Republic of Karelia is characterized by a weak seismicity. According to results of processing in the last 20 years, the magnitudes of seismic events recorded in this region did not exceed the value of 3.2. Earthquakes can occur 1-2 times a year. The most frequent seismic events on the Karelian seismic network records are industrial explosions. To determine the parameters of local events, various methods and location programs are used to obtain the most accurate results. More than 200 seismic events in different regions of Karelia are recorded annually.

Keywords: seismicity, center, seismic station, epicenter, magnitude, seismic map.

\section{Введение}

В Карелии действует сеть сейсмических станции на базе широкополосной аппаратуры Guralp CMG-6TD и CMG-3ESP (АЦП - GSR 24) (Шаров, 2007). Станции PTRZ, PITK, KOS6, PAAN установлены в специально оборудованных сейсмических павильонах на бетонные постаменты. Станция KOS6 располагается в 15 км от города Костомукша, PITK в поселке Леппясилта Питкярантского района, PTRZ в городе Петрозаводск. В 2016 г. заработала станция PAAN в Лоухском районе (Зуева, 2017). Согласно данным за последние два года были зарегистрированы сейсмические события в Костомукшском, Лахденпохском, Питкярантском, Сортавальском, Суоярвском, Прионежском, Кондопожском, Медвежьегорском, Пудожском и Лоухском районах.

\section{Определение параметров событий}

Для определения параметров локальных событий, зарегистрированных на территории Карелии, используются различные методы и программы локации, чтобы получить наиболее точные результаты (рис. 1).

Локация местных событий проводится в программном комплексе EIWIN, разработанным сотрудником КоФ ФИЦ ЕГС РАН В.Э. Асмингом (Асминг, 1997), с использованием скоростной модели BARENTS и в программном комплексе WSG, созданным в Единой Геофизической службе РАН (Служба срочных донесений). По собственным результатам обработки региональных сейсмических событий и по оценкам научных сотрудников Архангельской области, Кольского научного центра установлено, что скоростная модель BARENTS дает достаточно точные параметры эпицентров. С помощью перечисленных программ определяются основные параметры сейсмических событий (время в очаге, координаты эпицентра, локальная магнитуда). 


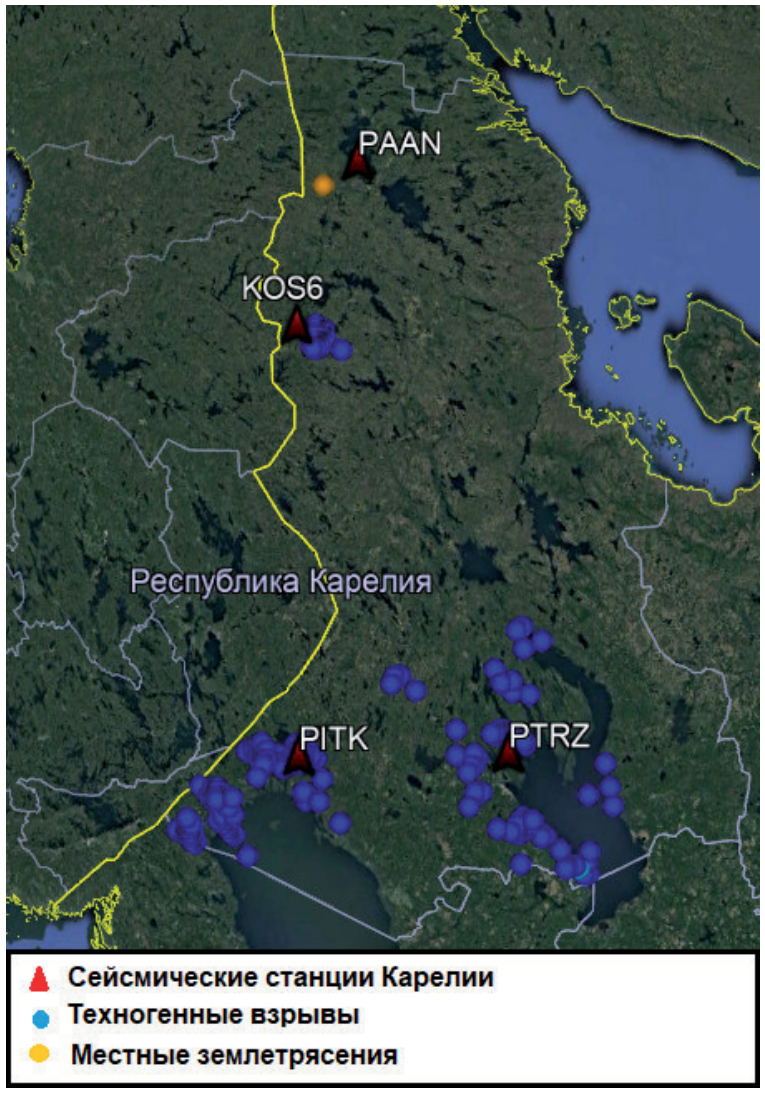

Рис. 1. Распределение эпицентров сейсмических событий на территории Карелии по результатам обработки (2017-2018 гг.).

Fig. 1. Distribution of epicenters of seismic events in Karelia according to the results of processing (2017-2018).
В обработке материалов используются данные Карельской сейсмической сети и соседних регионов. Первичная обработка события состоит из анализа волновых форм. По первым вступлениям объемных $\mathrm{P}$ и $\mathrm{S}$ волн на сейсмограмме можно наглядно определить район, где находился очаг (рис. 2).

В локации участвуют данные трех и более сейсмических станций. Координаты эпицентра определяются методом засечек. По полученным результатам обработки оценивается место взрыва или нахождение очага землетрясения.

Для идентификации сейсмических событий применяется спектральный анализ, который проводится в программном комплексе WSG. Если сравнивать амплитуды спектров двух и более событий, то можно оценить их удаленность до ближайшей сейсмической станции. Вследствие затухания от удаленных точек волны приходят с небольшим разбросом амплитуд (рис. 3) (Шаров, 1993).

Карьер «Центральный» располагается в 15 км, а карьер «Западный» в 25 км от станции KOS6. Максимальное значение амплитуды спектра взрыва 28.03.2018 превосходит максимум амплитуды взрыва 06.03.2018 в 3 раза.

Полученные результаты обработки (время очаге, координаты эпицентра и локальная магнитуда) используются для составления ежегодных каталогов и карт сейсмичности региона.

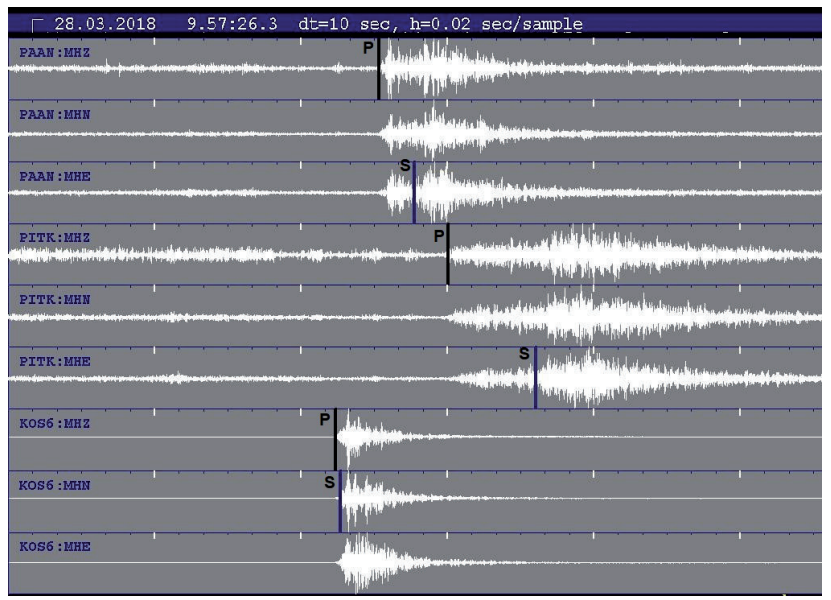

Рис. 2. Волновые формы взрыва 28.03.2018 на карьере «Центральный», Костомукшский район. Станции, записавшие события: KOS6, PAAN, PITK.

Fig. 2. Wave forms of an explosion on March 28, 2018 at the Central quarry, Kostomuksha district. Stations that recorded events: KOS6, PAAN, PITK.

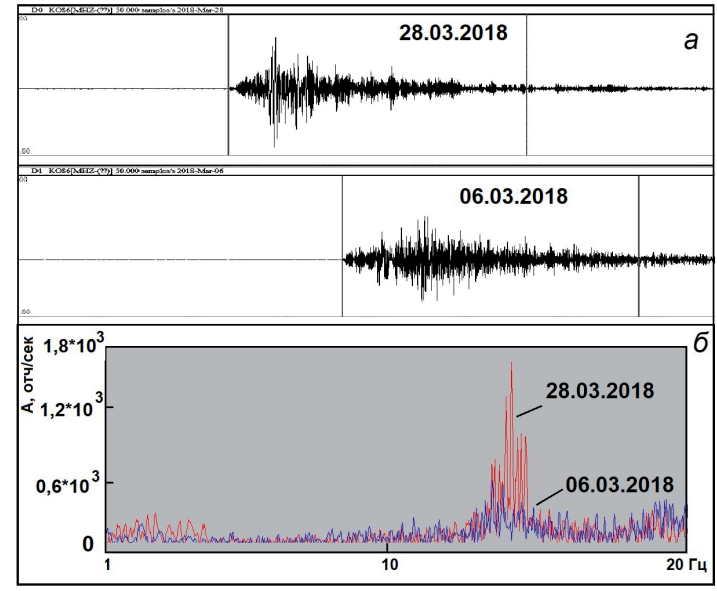

Рис. 3. Взрывы в Костомукшском районе на карьере «Центральный» 28.03.2018 $(\mathrm{ML}=1,8)$ и на карьере «Западный» 06.03.2018 (ML=2): $a$ - волновые формы; б - амплитудные спектры событий.

Fig. 3. The explosions in the Kostomuksha district at the Central quarry on March 28, $2018(\mathrm{ML}=1.8)$ and at the Western quarry on March 6, $2018(\mathrm{ML}=2)$ : a - wave forms; $b$ - amplitude spectra of events. 


\section{Выводы}

Ежегодно на территории Карелии регистрируются более 200 сейсмических событий техногенного и природного происхождения.

Исследование выполнено при финансовой поддержке РФФИ в рамках научного проекта № 18-35-00003.

\section{Литература}

1. Асминг В.Э. Программный комплекс для автоматизированной обработки сейсмических записей «EL» / Приборы и методика геофизического эксперимента. Мурманск: Изд-во ООО «МИП-999». 1997. С. 125-132.

2. Зуева И.А. и др. Характерные черты сейсмических записей промышленных взрывов на Костомукшском железорудном месторождении по данным станций Карельской сети // Вестник Воронежского государственного университета. Сер.: Геология. 2017. № 2. С. 133-141.

3. Служба Срочных Донесений. - Режим доступа: http://www.ceme.gsras.ru/new/soft.htm (дата обращения 15.02.2019.)

4. Шаров Н.В. Литосфера Балтийского щита по сейсмическим данным. Апатиты: КНЦ РАН. 1993. 145 с.

5. Шаров Н.В. и др. Землетрясения и микросейсмичность в задачах современной геодинамики ВосточноЕвропейской платформы. Петрозаводск: Карельский научный центр РАН. Кн. 1: Землетрясения. 2007. 381 с. 